The University of Southern Mississippi

The Aquila Digital Community

Faculty Publications

2009

\title{
Survey of Blueberry (Vaccinium spp.) Problems in the Gulf South
}

Melinda A. Miller-Butler

University of Southern Mississippi, melinda.miller@eagles.usm.edu

Kenneth J. Curry

University of Southern Mississippi, Kenneth.Curry@usm.edu

Barbara J. Smith

USDA-ARS Southern Horticultural Laboratory, barbara.smith@ars.usda.gov

Jeffrey S. Braswell

Mississippi Cooperative Extension Service

Follow this and additional works at: https://aquila.usm.edu/fac_pubs

Part of the Fruit Science Commons

\section{Recommended Citation}

Miller-Butler, M. A., Curry, K. J., Smith, B. J., Braswell, J. S. (2009). Survey of Blueberry (Vaccinium spp.) Problems in the Gulf South. Acta Horticulturae, 810, 369-377.

Available at: https://aquila.usm.edu/fac_pubs/74

This Article is brought to you for free and open access by The Aquila Digital Community. It has been accepted for inclusion in Faculty Publications by an authorized administrator of The Aquila Digital Community. For more information, please contact Joshua.Cromwell@usm.edu. 


\title{
Survey of Blueberry (Vaccinium spp.) Problems in the Gulf South
}

\author{
M.A. Miller-Butler ${ }^{\mathrm{a}}$ and K.J. Curry \\ Department of Biological Sciences \\ University of Southern Mississippi \\ Hattiesburg, Mississippi \\ USA
}

\author{
B.J. Smith \\ USDA-Agriculture Research Service \\ Southern Horticultural Laboratory \\ Small Fruits Research Unit \\ Poplarville, Mississippi \\ USA
}

\section{J. Braswell \\ Mississippi Cooperative Extension Service \\ Poplarville, Mississippi \\ USA}

Keywords: Vaccinium ashei Reade, V. virgatum Ait., V. corymbosum L., Phytophthora cinnamomi Rands, root rot

\begin{abstract}
The blueberry (Vaccinium) industry in Mississippi has been steadily increasing since the early $1980 \mathrm{~s}$, but some plants in older fields are now in decline. The root rot pathogen, Phytophthora cinnamomi, is endemic in the southeastern United States and has caused severe losses to blueberries in North Carolina and Arkansas. Because the warm, humid climate of Mississippi, with periods of high precipitation, provides a favorable environment for Phytophthora root rot disease, it was suspected to be the cause of plant decline in older blueberry fields. Members of the Gulf South Blueberry Growers Association were mailed surveys to determine cultural practices and the extent of losses in their blueberry fields. The survey was written in partial, open-ended question format with 33 questions pertaining to cultivars, number of hectares planted, cultural practices, overall health of the blueberry plants, and losses due to diseases, insects, or other problems. Fifty-eight of 146 surveys $(40 \%)$ were completed and returned. $89 \%$ of respondents grew rabbiteye (Vaccinium ashei) cultivars and the balance grew southern highbush $(V$. corymbosum hybrids) cultivars. The average number of plants per hectare was $\mathbf{1 5 2 3}$ with the majority of plants 10 - 20 years old. $79 \%$ of the growers described the overall condition of their plants as average, healthy, or vigorous. The most common cause of plant death cited was environmental with damage caused by the 2004 and 2005 hurricanes at the top of the list. No major diseases were reported by $36 \%$ of the respondents, while mummy berry (Monilinia vaccinii-corymbosi [Reade] Honey), leaf spots (many causal organisms), and root rot (Phytophthora cinnamomi Rands) were noted as problems by 22,15 , and $10 \%$ of the growers, respectively. Phytophthora species were isolated from root and soil samples collected from symptomatic plants on three farms. Weeds were listed as problems on $100 \%$ of the surveys. $47 \%$ of the respondents plan to increase their blueberry plantings mainly with rabbiteye cultivars.
\end{abstract}

\section{INTRODUCTION}

Rabbiteye blueberries, Vaccinium ashei Reade (syn. V. virgatum Ait.), and southern highbush blueberry, $V$. corymbosum L. hybrids, are grown commercially in Mississippi. Rabbiteye blueberries are native to the southeastern United States, are tolerant to heat and drought, can grow on a wide range of soil types (Austin, 1994), and produce abundant fruit with peak ripening in June and July. Increased consumer demand for early production of fresh blueberries has led to the development of southern highbush blueberry, cultivars that are the result of crosses between $V$. corymbosum and various

à Melinda.Butler@ars.usda.gov 
blueberry species native to the southeastern U.S. Southern highbush fruit ripens in May, extending the harvest season 4-5 weeks earlier. Rabbiteye and southern highbush blueberries are excellent commercial fruit crops for Mississippi. Fruit are not usually harvested from newly established blueberry fields until the third year and full production is not reached until the fifth year. During the five year establishment period, growers invest a large amount of time, money, and effort before returns are seen.

Blueberry farms are a small but growing industry in Mississippi. Commercial blueberry farming began in Mississippi with approximately 81 hectares planted in 1981 . The berries sold for $\$ 1.10$ - 1.65 per kilogram as "pick-your-own" fruit or at roadside stands. An estimated 567 hectares were planted by 1994 and 971 hectares were planted by 2005. The volume of blueberries sold through the three major marketing groups in Mississippi in 2005 was more than 2.6 million kilograms sold at \$ 2.79 per kilogram. In 2006 the volume was 1.75 million kilograms at $\$ 3.83$ per kilogram. The decrease in the 2006 volume was a result of damage to blueberry fields from Hurricane Katrina in August 2005 , but the price per kilogram increased. The volume of blueberries in 2007 was more than double the 2006 volume at 3.57 million kilograms sold at \$ 3.78 per kilogram.

The root rot pathogen, Phytophthora cinnamomi Rands, is endemic to the southeastern United States and has caused severe losses to blueberries in North Carolina (Zentmyer, 1980) and Arkansas (Clark et al., 1986). Phytophthora root rot is considered to be one of the major diseases of blueberry and has the ability to become a serious concern in many growing areas. (Caruso and Ramsdell, 1995) The above-ground symptoms of this disease are discoloration of the leaves (yellowing or reddening), defoliation, and stunted growth. Below ground symptoms include a reduction in the number of roots and root necrosis. Phytophthora cinnamomi produces motile zoospores capable of swimming to the roots of a host plant when excess water is available in the soil. When a host is not available the zoospores can encyst and then germinate at a later time during favorable conditions. Southern highbush blueberries are susceptible to $P$. cinnamomi, but rabbiteye exhibit some tolerance to the pathogen. Mississippi's warm, humid climate, with periods of high precipitation, provides a favorable environment for Phytophthora root rot disease which was thought to be the cause of plant decline that has been reported in older fields. A survey of blueberry growers in Mississippi, Alabama, and Louisiana was conducted to determine cultural practices being used, problems they were experiencing, and the extent of decline in commercial blueberry fields. This survey also identified potential locations for collecting P. cinnamomi.

\section{MATERIALS AND METHODS}

Members of the Gulf South Blueberry Growers Association whose farms are located in Louisiana, Mississippi, and Alabama were surveyed to determine the extent of losses due to Phytophthora root rot and other diseases in their plantings. The growers were also asked about other major problems occurring in their fields. The survey (Appendix A) was written in partial, open-ended question format with 33 questions pertaining to the cultivars, number of hectares planted, cultural practices, and the overall health of the blueberry plants.

The survey was also used to identify farms with potential Phytophthora root rot problems. Blueberry roots and soil were collected from symptomatic plants on three of these farms and used to attempt isolation of $P$. cinnamomi using a floating leaf baiting technique. Twenty-five grams of soil were placed in a $125 \mathrm{ml}$ glass jar, deionized water was added to cover the soil to a depth of $2 \mathrm{~cm}$, and eight 3-5 mm pieces of camellia leaf were floated in each jar. The jars were covered for 3 days at room temperature in light. On the third day the leaf pieces were removed and blotted dry on paper towels. A Phytophthora specific agar, PARPHV8 (Ferguson and Jeffers, 1999), was prepared and the leaf pieces were slipped under the agar. The plates were inspected after 3 and 5 days for fungal growth. 


\section{RESULTS AND DISCUSSION}

58 of the 146 surveys mailed to members of the Gulf South Blueberry Growers Association were completed and returned. The completed surveys represent over 202 hectares of blueberries. The average number of plants per hectare was 1523 with the majority of plants being 10-20 years old. 11\% of the plants being grown were southern highbush cultivars and $89 \%$ were rabbiteye cultivars with the majority represented by 'Tifblue' (22\%), 'Premier' (23\%), 'Climax' (23\%), and 'Brightwell' (14\%). 79\% of the respondents considered the overall condition of their plants as average, healthy, or vigorous while $19 \%$ described their plants as declining. $69 \%$ of the growers reported having sandy or sandy-loam soil. Soil amendments (mainly bark) were added at planting by $80 \%$ of the growers. $47 \%$ of growers did not use mulch on their plants. Most blueberry growers irrigated their plants using drip line with individual emitters $(41 \%)$ or drip tape (21\%). Most based their decision to irrigate on rainfall and $50 \%$ of the respondents reported the duration of each irrigation as 1-8 hours. Granular fertilizers were used by $76 \%$ of the respondents while $9 \%$ used organic fertilizers. Mummy berry, leaf spot, and root rot were noted as problems by 22,15 , and $10 \%$ of the growers, respectively. No major diseases were reported by $36 \%$ of the growers, and $59 \%$ did not use fungicides. The most frequently used fungicides were reported as $12 \%$ captan (Captan $50 \mathrm{WP}$, Micro Flo Company, Memphis, TN, USA), 16\% fenbuconazole (Indar, Dow AgroSciences, Indianapolis, IN, USA), and 5\% pyraclostrobin + boscalid (Pristine, BASF, Research Triangle Park, NC, USA). Insects do not represent a problem for $43 \%$ of the growers and $53 \%$ noted they did not use insecticides. $100 \%$ of the growers reported weed problems. $52 \%$ of the respondents used pre-emergence herbicides and $83 \%$ used post-emergence herbicides. $41 \%$ responded that environmental or accidental injury was the most likely cause of blueberry deaths on their farms. The most common cause of plant death was cited as environmental with damage caused during the 2004 and 2005 hurricane seasons at the top of the list. Most respondents plan to increase their blueberry acreage.

Many different soil organisms were recovered from the soil and roots using the floating leaf baiting technique. Thirty-two isolates obtained from the Phytophthora specific agar, displaying typical Phytophthora cinnamomi morphology, were tested using a Phytophthora genus only alkaline phosphatase label ELISA test (Phytophthora PathoScreen ${ }^{\circledR}$ Kit, Catalog \# PSA 92600; Agdia, Elkhart, IN, USA). Fourteen isolates tested positive.

Before conducting the grower survey, our perception was that older cultivated blueberry bushes in the Gulf South were in a decline, and that this decline might be caused by Phytophthora root rot. The survey was developed to determine if the older bushes in the Gulf South were actually in decline, and if there was a coinciding cultural practice or disease causing or adding to this decline. The survey asked pertinent questions about the cultivars planted, health of the plants, and cultural practices used by Gulf South blueberry growers. One problem when conducting a survey through the mail is obtaining sufficient completed surveys to lend weight to the information gathered. $40 \%$ of the surveys were completed and returned. The results would have yielded a better overall picture of blueberry farms in the Gulf South if more surveys had been completed. A decline in older bushes was not evident from the survey. Most growers answering this survey did not experience any unusual diseases in their blueberry fields, and premature deaths were not a problem, except those caused by environmental or accidental events. The environmental deaths were primarily from the 2004 and 2005 hurricane seasons that destroyed many hectares of farm and timberland in the Gulf South. Most growers preferred planting rabbiteye cultivars that are more resistant or tolerant to P. cinnamomi than highbush cultivars (Milholland, 1975). The sandy to sandy-loam soil reported by most growers is also a deterrent in the development of root rot diseases. Well-drained soil helps to decrease the occurrence of Phytophthora root rot disease (Zentmyer, 1980). The survey did not support the suggestion of a decline in older cultivated blueberry plants in the Gulf South or any specific disease problems. 


\section{ACKNOWLEDGMENTS}

We would like to thank the growers who answered the survey and the Gulf South Blueberry Growers Association.

Mention of a trademark, proprietary product, or vendor does not constitute a guarantee or warranty of the product by the U.S. Department of Agriculture and does not imply its approval to the exclusion of other products or vendors that also may be suitable.

\section{Literature Cited}

Austin, M.E. 1994. Rabbiteye Blueberries: Development, Production, and Marketing. AGSCIENCE, Inc. Auburndale, FL. 160 pp.

Caruso, F.L. and Ramsdell, D.C. 1995. Compendium of Blueberry and Cranberry Diseases. APS PRESS. St. Paul, MN. 87 pp.

Clark, J.R., Moore, J.N. and Draper, A.D. 1986. Inheritance of resistance to Phytophthora root rot in highbush blueberry. J. Amer. Soc. Hort. Sci. 11:106-109.

Ferguson, A.J. and Jeffers, S.N. 1999. Detecting multiple species of Phytophthora in container mixes from ornamental crop nurseries. Plant Dis. 83:1129-1136.

Milholland, R.D. 1975. Pathogenicity and histopathology of Phytophthora cinnamomi on highbush and rabbiteye blueberry. Phytopathol. 65:789-793.

Zentmyer, G.A. 1980. Phytophthora cinnamomi and the diseases it causes. Monograph 10. American Phytopathological Society. St. Paul, Minn. 96 pp.

\section{Appendix A}

\section{Southern Region Blueberry Growers Survey Results}

The total number of 58 respondents or the percentage of respondents is indicated following each question.

1. How many acres of blueberries do you have?

$\begin{array}{ll}<1 & 6 \\ 1-5 & 21 \\ 6-10 & 10 \\ 11-20 & 13 \\ 21-50 & 4 \\ >50 \text { acres } & 4\end{array}$

2. How many plants per acre?

617 Average

3. When were your blueberries planted? Indicate the percentage of plants in each age group. Average \%

$\begin{array}{ll}\text { Prior to } 1986 & 20 \\ 1986-1991 & 36 \\ 1992-1996 & 23 \\ 997-2001 & 7 \\ 2002-2004 & 13 \\ 2005-2006 & 7\end{array}$


4. Which rabbiteye cultivars do you have? Indicate the percentage of each rabbiteye cultivar.

$\begin{array}{ll}\text { Tifblue } & 25 \\ \text { Premier } & 25 \\ \text { Climax } & 26 \\ \text { Brightwell } & 15 \\ \text { Powderblue } & 4 \\ \text { Austin } & 3 \\ \text { Other } & 4\end{array}$

5. Which southern highbush cultivars do you have? Indicate the percentage of each highbush cultivar.

$\begin{array}{ll}\text { Star } & 2 \\ \text { Misty } & 2 \\ \text { Legacy } & 2 \\ \text { Other } & 6\end{array}$

6. What state was the nursery located that you obtained your blueberry plants from?
MS
LA
5
AL
5
FL
1
GA
$\mathrm{NC}$
10
Propagated own
2

7. What soil type is most common in your blueberry planting?
Sandy
Sandy loam
7
Loamy clay
33
Clay
11
Other
5

8. When planting the blueberries, what soil amendment (if any) was added? Indicate the amount of soil amendment incorporated.

$\begin{array}{ll}\text { None } & 12 \\ \text { Peat } & 22 \\ \text { Bark } & 20 \\ \text { Other } & 5\end{array}$

9. What type of mulch (if any) do you use on your blueberry plants?
No mulch
Hay
27
Pine straw
3
Bark
2
Other
16
7

10. often do you replenish the mulch? If you do not mulch, disregard this question.

Once/year

Every 2 years

5

When roots are visible

Other 
11. What is the source of your irrigation water?

$\begin{array}{ll}\text { Do not irrigate } & 9 \\ \text { Pond } & 8 \\ \text { Shallow well } & 9 \\ \text { Deep well } & 28 \\ \text { Community } & 3\end{array}$

12. What determines your decision to irrigate? If you do not irrigate, disregard this question.

$\begin{array}{ll}\text { Feel of soil } & 5 \\ \text { Lack of rain } & 36 \\ \text { Tensiometer } & 2 \\ \text { Other } & 3\end{array}$

13. How often do you irrigate? If you do not irrigate, disregard this question.

$\begin{array}{ll}\text { Daily } & 12 \\ \text { Three times/week } & 12 \\ \text { Twice/week } & 8 \\ \text { Once/week } & 5 \\ \text { Other } & 10\end{array}$

14. How long do you normally let the irrigation run? If you do not irrigate, disregard this question.

$\begin{array}{ll}1-4 \text { hours } & 15 \\ 5-8 \text { hours } & 14 \\ 9-12 \text { hours } & 6 \\ >12 \text { hours } & 6 \\ \text { Other } & 5\end{array}$

15. What kind of irrigation system do you use? If you do not irrigate, disregard this question.

$\begin{array}{ll}\text { Drip tape } & 12 \\ \text { Individual emitter } & 24 \\ \text { In-line emitter } & 21 \\ \text { Other } & 13\end{array}$

16. What type of fertilizer do you normally use? Indicate the formulation.

$\begin{array}{ll}\text { Granular, fast release } & 22 \\ \text { Granular, slow release } & 17 \\ \text { Granular, acid forming } & 6 \\ \text { Liquid } & 3 \\ \text { Organic } & 5 \\ \text { Other } & 5\end{array}$

17. How often do you apply fertilizers?

$\begin{array}{ll}\text { Never } & 3 \\ \text { Once/year } & 12 \\ \text { Twice/year } & 27 \\ \text { Three times/year } & 6 \\ \text { Monthly } & 2 \\ \text { Other } & 7\end{array}$


18. How do you decide which fertilizer to use?

$\begin{array}{ll}\text { Blueberry bulletin } & 11 \\ \text { Based on soil test } & 18 \\ \text { Based on foliar test } & 2 \\ \text { Farm advisor } & 4 \\ \text { Same as my neighbor } & 10 \\ \text { Other } & 12\end{array}$

19. What are your major disease problems? Check all that apply.

$\begin{array}{ll}\text { None } & 21 \\ \text { Mummy berry } & 13 \\ \text { Leaf spot } & 9 \\ \text { Root rot } & 6 \\ \text { Other } & 3\end{array}$

20. Which fungicides have you used in the past 3 years? Check all that apply.

$\begin{array}{ll}\text { None } & 34 \\ \text { Captan } & 7 \\ \text { Indar } & 9 \\ \text { Pristine } & 3 \\ \text { Other } & 2\end{array}$

21. What are your major insect problems? Check all that apply.

$\begin{array}{ll}\text { None } & 25 \\ \text { Gall midge } & 11 \\ \text { Thrips } & 3 \\ \text { Caterpillars } & 4 \\ \text { Cranberry fruit worm } & 6 \\ \text { Blueberry maggot } & 1 \\ \text { Other } & 7\end{array}$

22. Which insecticides have you used in the past 3 years? Check all that apply.

$\begin{array}{ll}\text { None } & 31 \\ \text { Imidan } & 4 \\ \text { Malathion } & 13 \\ \text { Sevin } & 2 \\ \text { Other } & 5\end{array}$

23. What are your major weed problems? Check all that apply.

$\begin{array}{ll}\text { None } & 1 \\ \text { Broadleaf weeds } & 42 \\ \text { Nutsedge } & 4 \\ \text { Annual grasses } & 42 \\ \text { Perennial grasses } & 7 \\ \text { Blackberry brambles } & 41 \\ \text { Vines } & 12 \\ \text { Other } & 6\end{array}$


24. Which pre-emergence herbicides have you used in the past 3 years? Check all that apply.

$\begin{array}{ll}\text { None } & 28 \\ \text { Karmex } & 3 \\ \text { Princep } & 5 \\ \text { Simazine } & 11 \\ \text { Sinbar } & 2 \\ \text { Solicam/Zorial } & 3 \\ \text { Surflan } & 2 \\ \text { Other } & 2\end{array}$

25. Which post-emergence herbicides have you used in the past 3 years? Check all that apply.

$\begin{array}{ll}\text { None } & 10 \\ \text { Gramoxone } & 2 \\ \text { Poast } & 4 \\ \text { Rely } & 9 \\ \text { Roundup/Glyphosate } & 31 \\ \text { Other } & 2\end{array}$

26. When do you prune your blueberry plants?

$\begin{array}{ll}\text { Every summer } & 23 \\ \text { Every winter } & 4 \\ \text { Every 2 or more years } & 19 \\ \text { Never } & 6 \\ \text { Other } & 5\end{array}$

27. What method do you use to harvest the blueberries? Indicate the percentage of berries harvested by each method.

$\begin{array}{ll}\text { Hand picked by local labor } & 21 \\ \text { Hand picked by migrant labor } & 22 \\ \text { Pick your own operation } & 20 \\ \text { Mechanical by owner } & 23 \\ \text { Custom mechanical } & 3 \\ \text { Catch Frame } & 4 \\ \text { Other } & 5\end{array}$

28. Are your blueberries cooled before packing and or shipping?
Yes
No
41
9

29. How do you pack your blueberries for market? Indicate the percentage of berries packed by each method.

All on farm sales $\quad 6$

Pick your own 10

Packed on farm 23

Marketing association $\quad 38$

Value-added products 3

Other 8 
30. How would you describe the overall condition of your plants?

$\begin{array}{ll}\text { Vigorous } & 4 \\ \text { Healthy } & 17 \\ \text { Average } & 25 \\ \text { Declining } & 11\end{array}$

31. Indicate the percentage of each of your cultivars that have died in the last 5 years.

$\begin{array}{ll}\text { Tifblue } & 5 \\ \text { Premier } & 5 \\ \text { Climax } & 6 \\ \text { Brightwell } & 4 \\ \text { Powderblue } & 1 \\ \text { Austin } & 2\end{array}$

32. What do you think is the most likely cause of blueberry plant death on your farm?

Cultural

Environmental

2

Disease 8

Accidental injury $\quad 10$

Other 16

33. What are your plans in the next 5 years concerning your blueberry farm?

$\begin{array}{ll}\text { No change } & 15 \\ \text { Plant more rabbiteye } & 27 \\ \text { Plant more southern highbush } & 5 \\ \text { Sell my farm } & 4 \\ \text { Take out the older cultivars } & 3 \\ \text { Retire } & 2 \\ \text { Other } & 3\end{array}$


